\title{
側岸に樹木を有する直線礫床河川の安定横断河床形状

\author{
STABLE CHANNEL CROSS-SECTION OF STRAIGHT GRAVEL RIVERS \\ WITH TREES ON BANKS
}

\author{
泉典洋* ・池田駿 介** \\ By Norihiro IZUMI and Syunsuke IKEDA
}

\begin{abstract}
Effect of bank vegetation on the stable channel cross-section of straight gravel rivers is studied theoretically, in which singular perturbation and matched asymptotic expansion techniques are employed to derive the lateral distributions of depth-averaged fluid velocity and the bed shear stress. A condition of sediment incipient motion is imposed at the junction of the bed and the banks to derive the stable depth, and a formula for resistance to flow is used to obtain the stable width. It is revealed that a thicker vegetation yields a larger depth and a smaller width. Increasing discharge is found to increase the effect of vegetation. The analysis is found to agree reasonably well with available field data.

Keywords: vegetation, singular perturbation, matched asymptotic expansion, gravel rivers, self-formed channels
\end{abstract}

\section{1. 序 論}

環境保全の重要性が認識されている今日にあって, ウォーターフロントに代表される水辺環境に対する関心 には特に高いものがある. 河川環境についても例外では なく, 河岸やその周辺の植生の保存および植樹も, 今後 積極的に行われていくであろう.このような要請に応え るには植生の水理学的影響の解明がまず行われなければ ならない, 従来の研究は, 植生の流水抵抗に関するもの がほとんどであり，河道形状に対する影響については若 干の野外測定值が存在するのみである.以上のことから， 本研究では, 側岸部に植生が存在する河道の動的安定形 状とそのスケールについて理論的研究を行い, 実河川に 適用して植生の効果を明らかにする.

移動床を有する流路の境界面は，流水亡河床材料との 相互作用によって決定される．境界面がどのような形状 で安定となるかという問題は, 移動床水理学上の重要な 課題の 1 つとして, 従来から数多くの研究が行われてき $た^{1) ~ 5)}$. この問題は, 自らの河道を維持しながら下流へ

* 学生会員 工修 埼玉大学大学院理工学研究科 （于338 浦和市下大久保 255）

** 正会員 工博 埼玉大学教授 工学部建設基礎工学科 (同上)
土砂を輸送する動的安定河床形状の問題として一般化さ れる. Parker $\left.{ }^{6}\right)$ は，乱流による運動量の横断方向輸送を 考慮することによって, この動的安定問題を解明するこ とに初めて成功した. Ikeda ら”はその理論をさらに発 展させ, 混合粒径の効果を取り入れることによって理論 值と実験值および野外実測值との良好な一致をみてい る. 本研究はこれらの理論をもとにして, 河岸に植生が 存在する場合, 安定河床形状がどのような影響を受ける かを明らかにしたものである，なお，ここで対象として いるのは北アメリカでよくみられるような自然直線砂床 河川であり，植生は樹木群を想定している.

\section{2. 樹木のない河道の流速と底面せん断力の分 布}

まず，樹木のない場合を考える．Fig.1に示したよう に動的平衡状態にある河床形状は J 点を境界点として, 河床の土砂が輸送されている中央部と, 静的平衡状態に

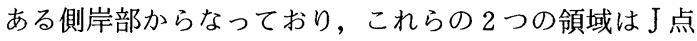
で滑らかにつながっている，もし流砂が存在する領域に 横断河床勾配が存在すれば，横断方向に流砂量が生じ河 床は安定となり得ない ${ }^{8)}$. したがって中央部は平坦と なっており, 次式が成り立つ.

$$
D=D_{c} \quad\left(0 \leqq y \leqq B_{c} / 2\right) \text {. }
$$




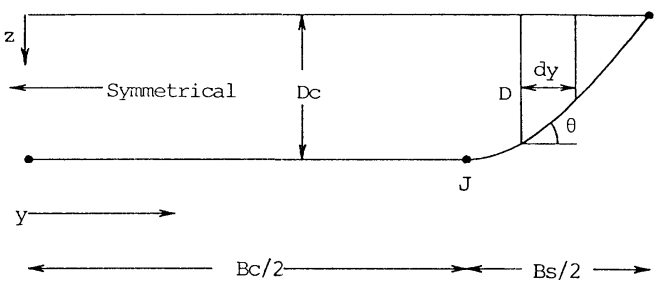

Fig. 1 Definition diagram of river without bank vegetation.

ここに, $D$ は水深， $D_{c}$ は中央部の水深で一定， $B_{c}$ は中 央部の幅である.もし側岸部で土砂が移動していれば横 断方向の土砂輸送が生じ, 限界掃流力状態となるまで川 は広がることとなる．したがって安定状態においては側 岸部では, 常に静的平衡状態にあり，斜面上の砂粒子に 働く力がつり合っている．したがって Lane ${ }^{3)}$ が導いた 静的平衡の式を用いて次のように表わされる.

$$
\begin{aligned}
& \left(\frac{\delta}{\delta_{c} \cos \theta}\right)^{2}+\left(\frac{1+\mu \beta}{\mu}\right)^{2}\left(\frac{d D}{d y}\right)^{2} \\
& =\mu^{2}\left(\frac{1+\mu \beta}{\mu}-\beta \frac{\delta}{\delta_{c} \cos \theta}\right)^{2} \quad\left(B_{c} / 2 \leqq y \leqq B / 2\right)
\end{aligned}
$$

ここに, $\delta=\tau / \rho g S, \tau$ は底面せん断応力, $\delta_{c}=\tau_{c} / \rho g S$ $\left(=D_{c}\right), \tau_{c}$ は水路中心における底面せん断応力, $\rho$ は 水の密度, $g$ は重力加速度, $S$ は縦断方向河床勾配, $\mu$ はクーロン静止摩擦係数, $\beta$ は砂粒子に働く揚力係数之 抗力係数の比, $B$ は水面における全川幅, $\theta$ は河床の横 断方向傾斜角である. 以後, 添え字 $c, s$ はそれぞれ河 道中央部と側岸部の值を表わす．河床に働くせん断力は 次のように表わされる9 .

$$
\frac{\tau}{\cos \theta}=\rho g D S+\frac{d}{d y} \int_{0}^{D}\left(-\rho \overline{u^{\prime} v^{\prime}}\right) d z
$$

ここに， $u^{\prime} ， v^{\prime}$ はそれぞれ流下方向, 横断方向の流速 変動成分である. 式（3）において乱流による運動量輸 送を微小として無視するならばては次のようになる。

$$
\tau=\rho g D S \cos \theta
$$

流砂量を算定する際, 式 (4) を用いると平坦な部分で はせん断力が一定となり，したがって中央部では一様な 流砂量が生じることになる，ところが，てが J 点で側岸 部に滑らかにつながる必要性から側岸部に流砂が存在す ることになり，川幅は際限なく広がっていく．このよう に式（4）を用いる限り, 動的安定河床形状の維持機構 を説明することは不可能となる. 元来, 式 (2), (3) は河床形状と流れの相互作用を表わしており，せん断力 分布を厳密に求めるには 2 つ式を連立させて解く必要 がある、ところが, 乱流による運動量輸送を考慮しなが ら連立して解くのは, 解析的には不可能である. そこで Parker $\left.{ }^{6}\right)$ は，まず式 (2)，（4）を連立させて側岸部の
$D$ を求め, その側岸形状と式（1）で表わされる中央 部の形状に対して, 乱流による運動量輸送によって再配 分された底面せん断応力を求めている.この際, 彼は Lundgren · Jonsson ${ }^{9)}$ の式を用いて底面せん断力を求め ているが, これは, 河床に対して垂直方向に, 流速分布 が対数則に従っているという仮定のもとに導かれたもの であり, 横断方向に緩やかに変化する河床形状をもった 流路を対象にしている. 河道の一部に樹木がある場合に は, 流速分布が必ずしも対数則に従わないばかりか ${ }^{10}$, 河床形状も緩やかに変化する保証はない。したがって, 本研究では後に樹木の効果を取り扱うため, Lundgren · Jonssonの式を用いず，以下に述べるように，水深平均 流速に抵抗係数を乗じてせん断力を求める方法をとる.

底面せん断応力之乱流による運動量の横断方向輸送量 は，流速を用いてそれぞれ次のように表わされる.

$$
\begin{aligned}
& \tau=\rho C_{f} \bar{u}^{2} \\
& \int_{0}^{D}\left(-\rho \overline{u^{\prime} v^{\prime}}\right) d z=\rho \epsilon_{y} D \frac{d \bar{u}}{d y}
\end{aligned}
$$

ここに, $\bar{u}$ は水深平均流下方向流速, $\epsilon_{y}$ は横断方向へ の運動量拡散係数であり,このような植生内部でも外部 とほぼ同じ值をとることが観測されている ${ }^{10)}$ 。これを用 いて式（3）を書き直すと次のようになる.

$$
\frac{\rho C_{f} \bar{u}^{2}}{\cos \theta}=\rho g D S+\rho \epsilon_{y} \frac{d}{d y}\left(D \frac{d \bar{u}}{d y}\right) .
$$

また, aspect 比 $\left(B / D_{c}\right)$ が十分に大きく, 側岸の影響 が河道中央に及ばない場合には次式が成立する.

$$
\tau_{c}=\rho C_{f} \bar{u}_{c}^{2}=\rho g D_{c} S
$$

式（7）を式（8）で割ると, 次のようになる.

$$
\frac{\sigma}{\cos \theta}=\frac{\phi^{2}}{\cos \theta}=s+\nu \frac{d}{d \eta}\left(s \frac{d \phi}{d \eta}\right)
$$

ここに, $\sigma=\tau / \tau_{c}, s=D / D_{c}, \nu=\epsilon_{y} D_{c} /\left[C_{f} \bar{u}_{c}\left(B_{s} / 2\right)^{2}\right]$, $\phi=\bar{u} / \bar{u}_{c}, \eta=\left(2 y-B_{c}\right) / B_{s}$, である.

$\epsilon_{y}=\alpha u_{* c} D_{c}$ と仮定すれば， $\nu$ は

$$
\nu=\frac{\epsilon_{y} D_{c}}{C_{f} \bar{u}_{c}\left(B_{s} / 2\right)^{2}}=\frac{\alpha}{\sqrt{C_{f}}}\left(\frac{2 D_{c}}{B_{s}}\right)^{2} .
$$

となる. Webel・Schatzman ${ }^{11)}$ によれば流路床が十分に 粗であれば， $\alpha$ はほぼ一定の值 0.13 をとる．また通常 の礫床河川では， $C_{f}$ の值は 0.01 程度であることが知ら れているから， $\alpha / \sqrt{C_{f}}$ はほぼ 1 となり， $2 D_{c} / B_{s}$ が微 小であればっも微小となる.したがって乱流による運 動量輸送の項を無視することは, 式（9）においてv の一次以上のオーダーの項を無視することに対応してい る.

側岸形状を表わす式 $(2)$ は同様な無次元化操作によっ て次のようになる.

$$
\left(\frac{\sigma}{\cos \theta}\right)^{2}+\left(\frac{1+r}{\mu}\right)^{2} \lambda\left(\frac{d s}{d \eta}\right)^{2}=\left(1+r-r \frac{\sigma}{\cos \theta}\right)^{2}
$$


ここに, $\lambda=\left(2 D_{c} / B_{s}\right)^{2}, \quad r=\mu \beta$ であり, $0 \leqq \eta \leqq 1 の$ 範 囲で式 (11) は成立する.

まず，式（9）の $\nu^{0}$ のオーダーを用いて式（11）を 解く. $\nu^{0}$ のオーダーは $\sigma / \cos \theta=s$ でるので, これ を式（11）に代入して次の解が得られる.

$$
\begin{aligned}
& s=\frac{1}{1-r}\left\{\cos \left(\eta \cos ^{-1} r\right)-r\right\} \\
& \lambda=\left(\frac{\mu}{\cos ^{-1} r}\right)^{2}\left(\frac{1-r}{1+r}\right) \cdots \cdots \ldots \ldots
\end{aligned}
$$

水際では水中安息角となるが，この值が 40 度のとき， $\mu=0.84, r=0.714$ となり $\lambda=0.196$ となる.

次に, 式 (12)のように得られた側岸形状および式 (1) で表わされる中央部 $s$ に対して，せん断力分布を式 (9) を用いて解く. 式 $(9)$ から中央部と側岸部に対し, そ れぞれ次の 2 つの方程式を得る.

$$
1+\nu d^{2} \phi / d \eta^{2}-\phi^{2}=0
$$

$s+\nu d(s d \phi / d \eta) / d \eta-\phi^{2} / \cos \theta=0$

$\nu$ は前述のように微小であるので， $\phi$ は $\nu$ 漸近展開に より

$$
\phi=\tilde{\phi}_{0}+\nu \tilde{\phi}_{1}+\nu^{2} \tilde{\phi}_{2}+\cdots
$$

と表わされることが期待される。式（16）を式（14）に 代入すると $\nu^{0}, \nu^{1}$ のオーダーに対し次式が得られる。

$$
\begin{aligned}
& 1-\tilde{\phi}_{0}^{2}=0 \\
& d^{2} \tilde{\phi}_{0} / d \eta^{2}-2 \tilde{\phi}_{0} \tilde{\phi}_{1}=0
\end{aligned}
$$

式 (17)，(18）の解として $\phi=1$ が得られるが，この解 は式(14)の 1 つの厳密解となっており, $\eta=-B_{c} / B_{s}$ (河 道中央）での境界条件を満たしている. ところが， $\eta=$ 0 (接合点 J) での境界条件は満たしていない，このこ とは式（17）において 2 次の微分項が微小として無視さ れていることによっており，式 (14) において に関する 2 階微分の項が， $\eta=0$ 近傍で無視できないほ ビ大きくなっていることを示している. すなわち $\phi=1$ は, 特異摂動問題における外部解となっている. 式 (14) の第 2 項が他の項とほぼ同じオーダーになるように特異 摂動法 ${ }^{12)}$ に従い, 内部変数 $p=\eta / \nu^{1 / 2}$ を導入する.こ のとき，式 (14)，(15) は

$$
\begin{gathered}
1+d^{2} \phi / d p^{2}-\phi^{2}=0 \cdots \ldots \ldots \ldots \ldots \ldots \ldots \ldots \ldots \\
s+d(s d \phi / d p) / d p-\phi^{2} / \cos \theta=0 \\
\text { となる. 式 }(19) \text { に } \phi \text { の漸近展開 }
\end{gathered}
$$

$$
\phi=\phi_{0}+\nu \phi_{1}+\nu^{2} \phi_{2}+\cdots
$$

を代入すると $\nu^{0}, \nu^{1}$ のオーダーに対し次の方程式が得 られる。

$$
\begin{aligned}
& 1+d^{2} \phi_{0} / d p^{2}-\phi_{0}^{2}=0 \\
& d^{2} \phi_{1} / d p^{2}-2 \phi_{0} \phi_{1}=0
\end{aligned}
$$

式 (22) の 1 つの㛜密解は $\phi_{0}=1$ であるから，これを用 いて式 (23) を解くと $\phi_{1}$ の一般解は次のようになる.

$$
\phi_{1}=C_{0} \exp (\sqrt{2} p)+C_{1} \exp (-\sqrt{2} p)
$$

外部解亡内部解の接続条件 ${ }^{12)}$ から $C_{1}=0$ となり, 式 (24) は次のようになる.

$$
\phi_{1}=C_{0} \exp (\sqrt{2} p)
$$

式（20）についても同様に解くことができるが，この 際 $s, 1 / \cos \theta$ が次のように表わされることに注意する 必要がある.

$$
\begin{aligned}
& s=s(0)+s_{\eta \eta}(0) \eta^{2} / 2+\cdots \\
& =1+\nu s_{\eta \eta}(0) p^{2} / 2+O\left(\nu^{2}\right) \ldots \ldots \ldots \ldots \ldots \ldots \ldots . . . \\
& \begin{aligned}
1 / \cos \theta & =\left(1+\tan ^{2} \theta\right)^{1 / 2} \\
& =1+(d D / d y)^{2} / 2-(d D / d y)^{4} / 8 \cdots \\
& =1+\lambda(d s / d \eta)^{2} / 2+O\left(\lambda^{2}\right) \cdots \cdots \cdots \cdots
\end{aligned}
\end{aligned}
$$

ここに， $\lambda=\left(\sqrt{C_{f}} / \alpha\right) \nu$ 関係があることを考慮し，式 (21)，(26)，(27）を式 (20) に代入し $\nu^{0}, \nu^{1}$ のーダー に対し次式を得る.

$$
\begin{aligned}
& 1+d^{2} \phi_{0} / d p^{2}-\phi_{0}^{2}=0 \cdots \cdots \cdots \cdots \cdots \cdots \cdots \cdots \cdots \cdots \cdots \cdots \cdots \\
& s_{\eta \eta}(0) p^{2} / 2+s_{\eta \eta}(0) p^{2}\left(d^{2} \phi_{0} / d p^{2}\right) / 2 \\
& +d^{2} \phi_{1} / d p^{2}+s_{\eta \eta}(0) p d \phi_{0} / d p-2 \phi_{0} \phi_{1}=0
\end{aligned}
$$

ここに, $s_{\eta \eta}$ は $s$ のによる 2 階微分を表わしている. 式 (28) の自明の解 $\phi_{0}=1$ を用いて式 (29) を解くと

$$
\phi_{1}=\bar{C}_{0} \exp (-\sqrt{2} p)-\gamma\left(p^{2}+1\right) / 2
$$

となる.ここに， $\gamma=-s_{\eta \eta}(0) / 2$ である。

接合点 $(p=0)$ では流速とせん断力が連続でなけれ ばならない．すなわち $\phi$ および $d \phi / d p$ が連続となる. この条件を用いて $C_{0}, \bar{C}_{0}$ を決定すると

$$
C_{0}=-\gamma / 4, \quad \bar{C}_{0}=\gamma / 4
$$

が得られる. 以上より接合点上での無次元流速 $\phi_{j}$ は次 のように表わされる.

$$
\phi_{j}=1-\nu \gamma / 4
$$

ここで， $\nu$ の值を調べてみる， $\alpha$ としては前述した値 0.13 を用いる. $C_{f}$ の值としては Keulegan の抵抗式 ${ }^{13)}$ $C_{f}=\left\{6+2.5 \ln \left(D_{c} / k\right)\right\}^{-2}$ を用い, $5 \leqq D_{c} / k \leqq 100$ の範 囲で平均した值 0.00445 を用いる.ここに $k$ は相当粗 度である．また，前述の議論から $\lambda=0.196$ である．以 上より

$$
\nu=\alpha \lambda / \sqrt{C_{f}}=0.382 \text {. }
$$

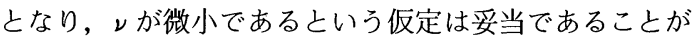
わかる。 また，このとき式（12）において $r=0.714$ を 用い $\gamma$ を求めると $\gamma=1.05$ となり， $\phi_{j}=0.900$ となる. 前にも述べたように接合点 $(p=0)$ においてちょうど 限界掃流力となっているので次式が成立する。

$$
\frac{\tau_{c}^{*}}{\tau_{t h}^{*}}=\frac{1}{\phi_{j}^{2}}=1.23
$$

ここに， $\tau_{c}^{*}$ は河道中央付近のせん断力， $\tau_{t h}^{*}$ は無次元限 界掃流力である. Ikeda らは Lundgren · Jonsson の式 から接合点でのせん断力と河道中央付近の底面せん断力 亡の関係を求め, $\tau_{c}^{*} / \tau_{t h}^{*}$ が $D_{c} / k$ の鈍い関数であるこ とから， $5 \leqq D_{c} / k \leqq 100$ の範囲での平均值を 1.23 とし 
ている.ここで得られた值はこの值と一致し，この理論 の妥当性が示唆される.

\section{3. 樹木を有する側岸部の形状}

樹木を有する場合も，河道は中央部と側岸部とに分け られる，側岸部は静的平衡状態にあり土砂が移動しない ため樹木は存在し続けることができる．ところが，中央 部では土砂が下流へ輸送されているため, 樹木は進出す ることができない，したがって，樹木は側岸部にのみ存 在し, 平坦な中央部では樹木は存在しない(Fig. 2 参照). このとき，側岸部の底面せん断応力は次のように表わさ れる.

$$
\begin{aligned}
\frac{\tau}{\cos \theta} & =\frac{\rho C_{f} \bar{u}^{2}}{\cos \theta} \\
& =\rho g D S-D_{r}+\rho \epsilon_{y} \frac{d}{d y}\left(D \frac{d \bar{u}}{d y}\right)
\end{aligned}
$$

ここで， $D_{r}$ は樹木による抗力であり次のように表わせ る.

$D_{r}=\rho C_{D}(a / \cos \theta) D \bar{u}^{2} / 2$

$a$ は樹木の密度を表わすパラメーターで $d /\left(l_{x} l_{y}\right)$

(Fig. 3 参照) と表わされる. 側岸部に働くせん断力を 流路中央の值を用いて無次元化すると式 (36) は

$$
\frac{\sigma}{\cos \theta}=s-\frac{\chi s \phi^{2}}{\cos \theta}+\nu \frac{d}{d \eta}\left(s \frac{d \phi}{d \eta}\right)
$$

となる.ここに, $\chi=C_{D} a D_{c} /\left(2 C_{f}^{\prime}\right)$ である. $\nu^{0}$ のオー
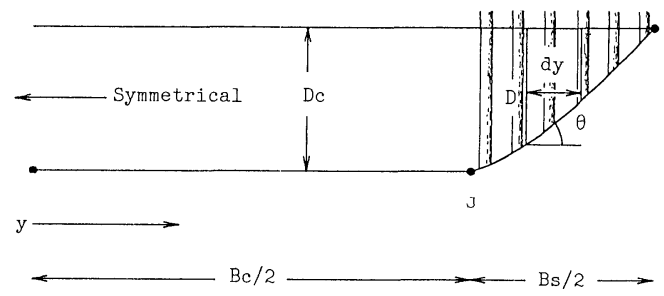

Fig. 2 Definition diagram of river with bank vegetation.

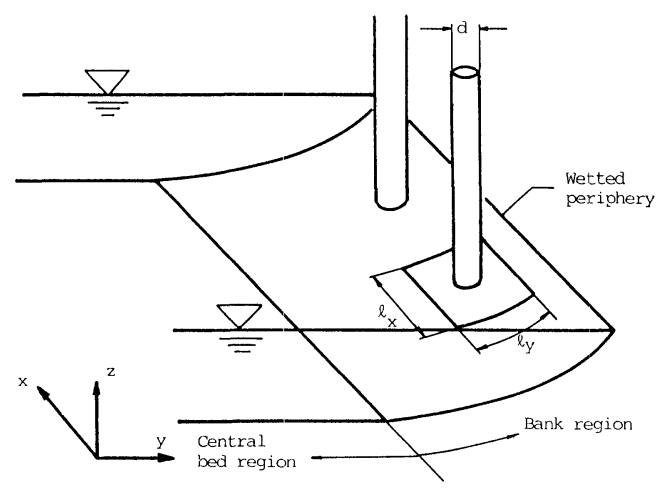

Fig. 3 Definition sketch of bank vegetation.
ダーまでとり， $\sigma=\phi^{2}$ を用いると, 式 (38) は次のよう に書き換えられる。

$\sigma / \cos \theta=s-\chi s \sigma / \cos \theta$

式 (39) から次式が得られる.

$$
\frac{\sigma}{\cos \theta}=\frac{s}{1+\chi s} \text {. }
$$

これを式 (11) に代入し, $s\left(=D / D_{c}\right)$ について解く と次のような解が得られる.

$$
\begin{aligned}
& \text { i ) } \chi<1 \text { の場合 } \\
& \left(1-\Theta^{2}+\chi \Omega \Theta\right) \cos ^{-1}\left(\frac{1-\Theta^{2}}{\Omega} s-\Theta\right) \\
& +\chi \Omega \sin \left\{\cos ^{-1}\left(\frac{1-\Theta^{2}}{\Omega} s-\Theta\right)\right\} \\
& =\lambda^{-1 / 2} \frac{\mu}{\Omega}\left(1-\Theta^{2}\right)^{3 / 2} \eta \\
& +\left(1-\Theta^{2}+\chi \Omega \Theta\right) \cos ^{-1}\{1-\chi(1+\Theta)\} \\
& +\chi \Omega \sin \left[\cos ^{-1}\{1-\chi(1+\Theta)\}\right] \text {. }
\end{aligned}
$$

ここに

$$
\begin{aligned}
\lambda^{1 / 2}= & \mu\left(1-\Theta^{2}\right)^{3 / 2} / A_{1} \cdots \ldots \ldots \ldots \ldots \ldots \\
A_{1}= & \Omega\left(1-\Theta^{2}+\chi \Omega \Theta\right)\left[\cos ^{-1}(-\Theta)\right. \\
& \left.-\cos ^{-1}\{1-\chi(1+\Theta)\}\right] \\
& +\chi \Omega^{2}\left[\sin \left\{\cos ^{-1}(-\Theta)\right\}\right. \\
& \left.-\sin \left\{\cos ^{-1}(1-\chi(1+\Theta))\right\}\right]
\end{aligned}
$$

ii ) $\chi>1$ の場合

$$
\begin{aligned}
& \left(\Theta^{2}-1-\chi \Omega \Theta\right) \cosh ^{-1}\left(\frac{\Theta^{2}-1}{\Omega} s+\Theta\right) \\
& +\chi \Omega \sinh \left\{\cosh ^{-1}\left(\frac{\Theta^{2}-1}{\Omega} s+\Theta\right)\right\} \\
& =-\lambda^{-1 / 2} \frac{\mu}{\Omega}\left(\Theta^{2}-1\right)^{3 / 2} \eta \\
& +\left(\Theta^{2}-1-\chi \Omega \Theta\right) \cosh ^{-1}\{\chi(1+\Theta)-1\} \\
& +\chi \Omega \sinh \left[\cosh ^{-1}\{\chi(1+\Theta)-1\}\right] \cdots \cdots
\end{aligned}
$$

$$
\text { ここに }
$$$$
\lambda^{1 / 2}=-\mu\left(\Theta^{2}-1\right)^{3 / 2} / A_{2}
$$

$A_{2}=\Omega\left(\Theta^{2}-1-\chi \Omega \Theta\right)\left[\cosh ^{-1} \Theta\right.$

$$
\begin{aligned}
& \left.-\cosh ^{-1}\{\chi(1+\Theta)-1\}\right] \\
& +\chi \Omega^{2}\left[\sinh \left(\cosh ^{-1} \Theta\right)\right. \\
& \left.-\sinh \left\{\cosh ^{-1}(\chi(1+\Theta)-1)\right\}\right]
\end{aligned}
$$

iii) $\chi=1$ の場合

$$
\begin{aligned}
& \{\Omega(\Omega+2 s)\}^{3 / 2} / 3 \Omega+(2-\Omega)\{\Omega(\Omega+2 s)\}^{1 / 2} \\
& =-2 \lambda^{-1 / 2} \mu \eta-\{\Omega(\Omega+2)\}^{1 / 2}(2 \Omega / 3-8 / 3) \cdots \cdots \\
\text { ここに } & \\
& \lambda^{1 / 2}=-2 \mu / A_{3} \cdots \cdots \cdots \cdots \cdots \cdots \cdots \cdots \cdots \cdots \cdots \cdots \cdots \cdots \cdots \cdots \cdots \cdots \cdots \cdots \\
& A_{3}=\Omega(2-2 \Omega / 3)+\{\Omega(\Omega+2)\}^{1 / 2}(2 \Omega / 3-8 / 3)
\end{aligned}
$$

上式中で, $\Omega=1+r, \Theta=\chi+\chi r-r$ である. また水中 安息角は $40^{\circ}$ とした. 得られた側岸部の形状 $s$ と $\sqrt{\lambda}=$ $2 D_{c} / B_{s}$ の值をそれぞれ Fig. 4, Fig. 5 に示す. 1つの 


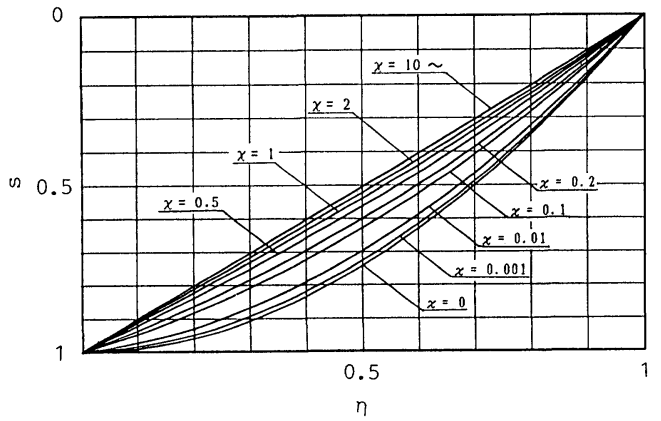

Fig. 4 Vegetated bank profiles.

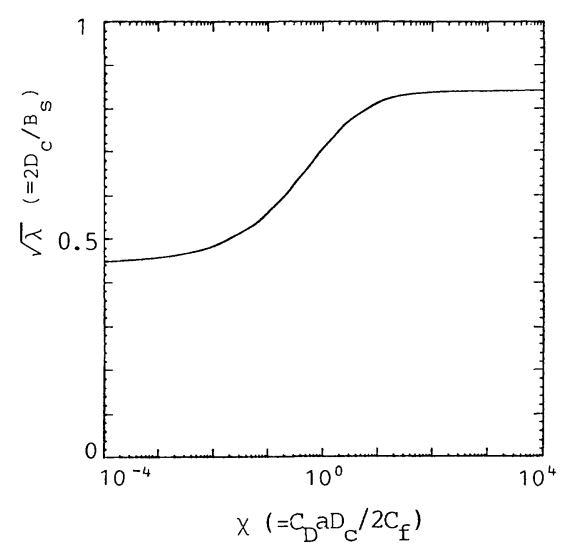

Fig. $5 \sqrt{\lambda}$ versus $\chi$.

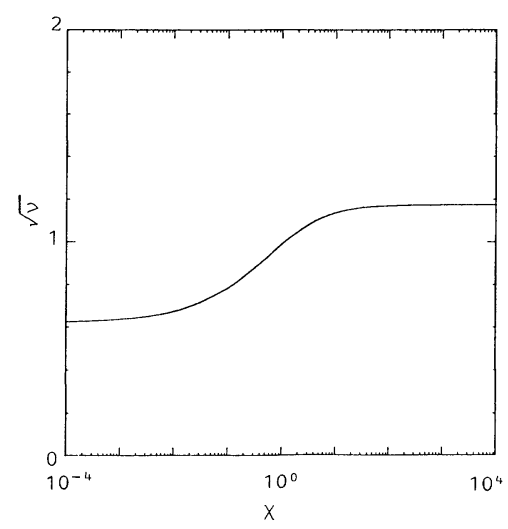

Fig. $6 \sqrt{\nu}$ versus $\chi$.

例として $\alpha=0.13, C_{f}=0.00445$ を用いて求められた $\sqrt{\nu}$ の值を $\chi$ の関数として Fig. 6 に示す.これから $\chi$ が増加するにつれて入の值が増加するため $\nu$ の值も増 加することが知られ， $\chi=2$ 以上では $\nu$ は 1 を越え摂動 近似の精度は保証されなくなる。

\section{4. 樹木を有する河道の横断方向流速分布}

樹木のない中央部および樹木のある側岸部について運 動量のつり合い式はそれぞれ次のようになる.

$$
\rho C_{f} \bar{u}^{2}=\rho g D_{c} S+\rho \epsilon_{y} D_{c} d^{2} \bar{u} / d y^{2}
$$

$\rho C_{f} \bar{u}^{2} / \cos \theta=\rho g D S-\rho C_{D} a D \bar{u}^{2} /(2 \cos \theta)$

$+\rho \epsilon_{y} d(D d \bar{u} / d y) / d y$

前之同様に無次元化を行い, 次の 2 つの式が得られる.

$$
1+\nu d^{2} \phi / d \eta^{2}-\phi^{2}=0
$$

$s+\nu d(s d \phi / d \eta) / d \eta-(1+\chi s) \phi^{2} / \cos \theta=0 \cdots$

式 (49)，(50) は樹木がない場合と同じ手続きによって 解かれるが, 式 $(41) \sim(46 \cdot b)$ を用いて $s$ が次のよう に展開されることに注意する必要がある.

$$
s=1+\nu^{1 / 2} s_{\eta}(0) p+\nu s_{\eta \eta}(0) p^{2} / 2+O\left(\nu^{3 / 2}\right) \cdots \cdots(51)
$$

$s$ が $\sqrt{\nu}$ に対し展開されることを考慮して $\phi$ を次のよ うに漸近展開する.

$$
\phi=\phi_{0}+\nu^{1 / 2} \phi_{1}+\nu \phi_{2}+\cdots
$$

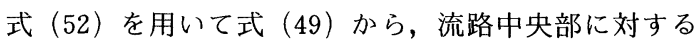
$\nu^{1}$ のオーダーまでの解を求めると

$$
\begin{aligned}
& \phi_{0}=1, \quad \phi_{1}=\tilde{C}_{0} \exp (\sqrt{2} p) \cdots \cdots \cdots \cdots \cdots \cdots \\
& \phi_{2}=C_{2} \exp (\sqrt{2} p)+\left(\tilde{C}_{0}^{2} / 6\right) \exp (2 \sqrt{2} p)
\end{aligned}
$$

となる．側岸部に対しては式（50）に（51），(27)，(52） を代入し，次の解が得られる.

$$
\begin{aligned}
& \phi_{0}=1 / \sqrt{1+\chi} \\
& \phi_{1}=\hat{C}_{0} \exp (-\sqrt{2} \sqrt[4]{1+\chi} p)+\frac{s_{\eta}(0)}{2(1+\chi)^{3 / 2}} p \\
& \phi_{2}=\hat{C}_{2} \exp (-\sqrt{2} \sqrt[4]{1+\chi} p) \\
& +\frac{\hat{C}_{0}^{2}(1+\chi)^{1 / 2}}{6} \exp (-2 \sqrt{2} \sqrt[4]{1+\chi} p) \\
& +\frac{\hat{C}_{0} s_{\eta}(0)}{4 \sqrt{2}(1+\chi)^{3 / 4}} p^{2} \exp (-\sqrt{2} \sqrt[4]{1+\chi} p) \\
& -\frac{4 \chi+3}{8(1+\chi)} \hat{C}_{0} s_{n}(0) p \exp (-\sqrt{2} \sqrt[4]{1+\chi} p) \\
& +\frac{2(1+\chi) s_{\eta \eta}(0)-(1+4 \chi) s_{\eta}^{2}(0)}{8(1+\chi)^{5 / 2}} p^{2} \\
& +\frac{s_{\eta \eta}(0)}{4(1+\chi)^{2}}-\frac{2 \chi-1}{8(1+\chi)^{3}} s_{\eta}^{2}(0) \\
& -\frac{\sqrt{C_{f}} s_{\eta}^{2}(0)}{4 \alpha(1+\chi)^{1 / 2}}
\end{aligned}
$$

ここでも, 積分定数の決定に際しては接合点における流 速とせん断力の連続，すなわち， $p=0$ において $\phi$ と $d \phi / d p$ が連続するという条件を用いている．積分定数 については付録を参照のこと.

\section{5. 安定水深と安定川幅}

まず，流速分布から底面せん断力分布を求め，これか ら安定水深を求める. 接合点での無次元流速 $\phi_{j}$ は式 (53) 
～(55) から次のように求められる.

$$
\phi_{j}=1+\nu^{1 / 2} \tilde{C}_{0}+\nu\left(C_{2}+\tilde{C}_{0}^{2} / 6\right) \cdot
$$

前にも述べたように接合点では限界掃流力状態が実現し ている. したがって $\tau_{j}^{*}=\tau_{t h}^{*}$ となる.ここに $\tau^{*}$ は無次 元せん断力であり $\tau^{*}=\tau /\left(R_{s} g d_{50} m\right), R_{s}=\left(\rho_{s}-\rho\right) / \rho$, $\rho_{s}$ は砂の密度, $d_{50}$ は $50 \%$ 粒径 (中央粒径), $m=$ $d_{90} / d_{50}, \tau_{t h}^{*}$ は無次元限界掃流力である. $\tau_{j}^{*}=\phi_{j}^{2} \tau_{c}^{*}$ で あるから流路中央の底面せん断力 $\tau_{c}^{*}$ と限界掃流力 $\tau_{t h}^{*}$ との比は

$$
\frac{\tau_{c}^{*}}{\tau_{t h}^{*}}=\frac{1}{\phi_{j}^{2}}
$$

となる.この比の值を， $\chi$ の関数として Fig. 7 に示した. Ikeda $ら^{7)}$ は限界掃流力として Egiazaroff ${ }^{14)}$ の式

$$
\tau_{t h}^{*}=\frac{0.05}{\left\{\log _{10}(19 m)\right\}^{2}}
$$

を用い，混合粒径の効果を取り入れている. 式（61）を 式（60）に代入すると流路中央部水深として

$$
D_{c}=\frac{0.05}{\phi_{j}^{2}} R_{s}\left\{\log _{10}(19 m)\right\}^{-2} d_{50} m S^{-1}
$$

が得られる. いくつかの代表的な勾配 $S$ について $\chi$ に よる $D_{c} / d_{50}$ の変化を Fig. 8 に示す.ここで $m$ の值は 代表的な值 $2^{7)}$ を用いてある. $\chi$ の増加，すなわち，樹 木密度の増加に伴い安定水深は増加することがわかる.

安定流路幅を求めるには, 流路全体の運動量のつり合 い式を用いる必要がある.その式は

$$
\rho C_{f} U^{2} B_{c}+\rho C_{s} \bar{u}_{s}^{2} P_{s}+\rho C_{D} a A_{s} \bar{u}_{s}^{2} / 2=\rho g A S
$$

となる.ここに， $U$ は中央部での平均流速， $\bar{u}_{s}$ は側岸 部での平均流速, $P_{s}$ は側岸部での潤辺， $A_{s}$ は側岸部の 断面積， $A$ は全断面積である， $P_{s}, A_{s}, A$ ，および径 深 $R$ の值は，前に求めた断面形状から次のように表わ される.

$$
\begin{aligned}
& P_{s}=F_{1}(\chi) D_{c} \cdots \cdots \cdots \cdots \cdots \cdots \\
& A_{s}=F_{2}(\chi) D_{c}^{2} \cdots \cdots \cdots \cdots \cdots \cdots \\
& A=\left\{1+F_{2}(\chi) \frac{D_{c}}{B_{c}}\right\} D_{c} B_{c} \\
& R=\left\{1-F_{3}(\chi) \frac{D_{c}}{B_{c}}\right\} D_{c} \cdots \cdots
\end{aligned}
$$

$F_{1}, F_{2}, F_{3}$ は $\chi$ の関数である. これらの值は式 (41) 〜 (46・b) の結果から得られるが, 解析的には求めら れない. そこで数值的に計算した值を Fig. 9 に示した. $\bar{u}_{s}$ の值は，式（56）で表わされる0次解から次のよう になる。

$$
\bar{u}_{s}=U / \sqrt{1+\chi}
$$

$C_{f}$ の值としては次式で表わされる Keulegan式を用い た.

$$
C_{f}=\{2.5 \ln (11 R / k)\}^{-2}
$$

式（64）（69）を式（63）に代入し $D_{c} / B_{c}$ を微小項と

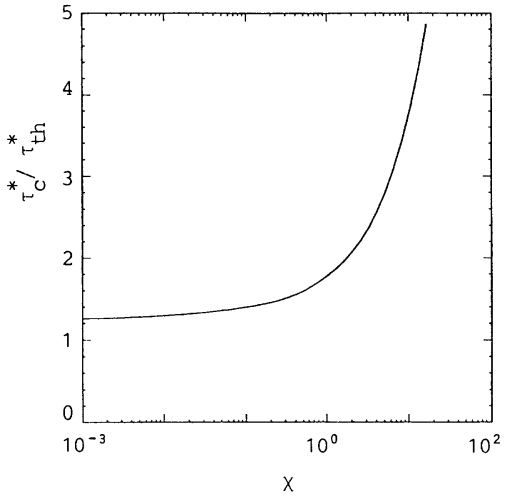

Fig. $7 \tau_{c}^{*} / \tau_{t h}^{*}$ versus $\chi$.

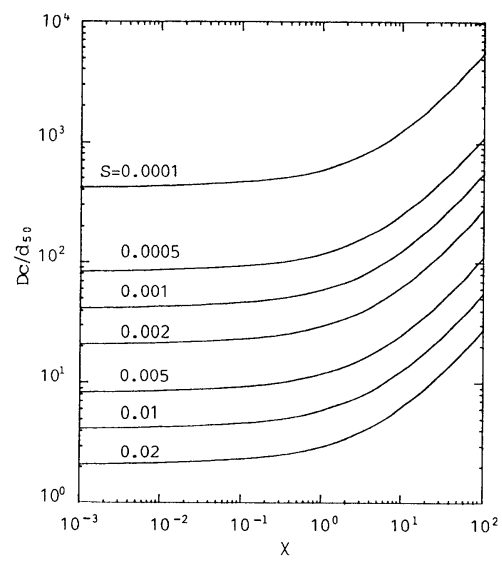

Fig. $8 D_{c} / d_{50}$ versus $\chi$ and $S ; m=2$.

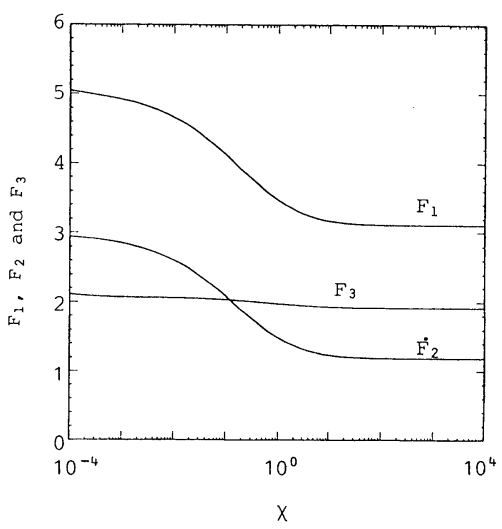

Fig. $9 F_{1}, F_{2}$ and $F_{3}$ versus $\chi$.

して展開した後， $D_{c} / B_{c}$ について 1 次のオーダーまで とると次式が得られる.

$$
\begin{aligned}
U= & \sqrt{g D_{c} S} \cdot 2.5 \ln \left(11 D_{c} / k\right) \\
& \times\left[1-\left\{\frac{1}{2(1+\chi)}+\frac{1}{\ln \left(11 D_{c} / k\right)}\right\} F_{3} \frac{D_{c}}{B_{c}}\right] \cdots(70)
\end{aligned}
$$



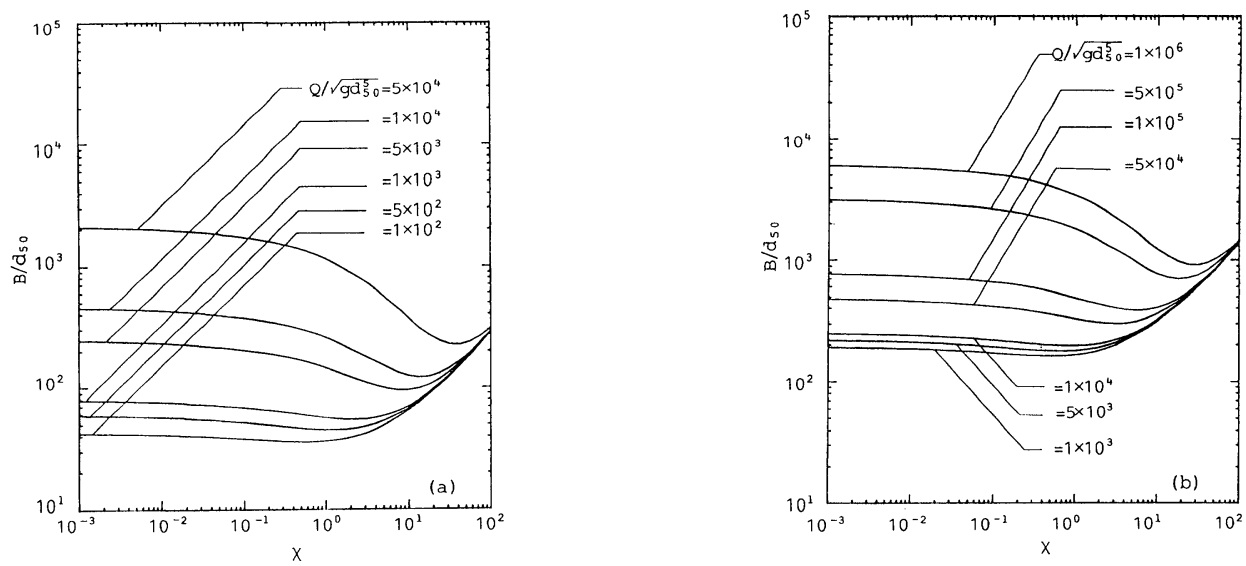

Fig. $10 B / d_{50}$ versus $\chi$ and $Q / \sqrt{g d_{50}^{5}}$; (a) $S=0.01, m=2$, (b) $S=0.002, m=2$.

また，全流量を $Q$ とすると次の関係式が得られる.

$$
Q=U B_{c} D_{c}+\bar{u}_{s} A_{s}=U\left(1+\frac{F_{2}}{\sqrt{1+\chi}} \frac{D_{c}}{B_{c}}\right) B_{c} D_{c}
$$

式 (70) と式 (71) から $U$ を消去し， $B_{c}$ について解く と次の関係式が得られる.

$$
\begin{aligned}
B_{c} & =\frac{Q}{\sqrt{g D_{c}^{3} S} \cdot 2.5 \ln \left(11 D_{c} / k\right)} \\
& +\left\{\frac{F_{3}}{2(1+\chi)}+\frac{F_{3}}{\ln \left(11 D_{c} / k\right)}-\frac{F_{2}}{\sqrt{1+\chi}}\right\} D_{c}
\end{aligned}
$$

$B_{s}=\left(2 / \lambda^{1 / 2}\right) D_{c}$ の関係を用いると全川幅 $B$ は次のよう に表わせる.

$$
\begin{aligned}
B= & \frac{Q}{\sqrt{g D_{c}^{3} S} \cdot 2.5 \ln \left(11 D_{c} / k\right)} \\
& +\left\{\frac{2}{\lambda^{1 / 2}}+\frac{F_{3}}{2(1+\chi)}\right. \\
& \left.+\frac{F_{3}}{\ln \left(11 D_{c} / k\right)}-\frac{F_{2}}{\sqrt{1+\chi}}\right\} D_{c}
\end{aligned}
$$

代表的な $Q$ と $S$ について, 式 (73) から得られる $\chi$ に よる $B / d_{50}$ の変化を Fig. 10 に示した. ここで $k$ の值と しては $k=1.5 d_{90}{ }^{7)}, m$ の值は代表値として $2^{7)}$ を用い ている，QとSの値については，野外観測の結果から， 実河川に対応する值を用いた。これによると次に示す理 論の適用限界 $\chi=7$ 以下の領域では $\chi$ の増加に伴って川 幅が減少することがわかる.

\section{6. 理論の適用限界}

ここで, 実際の河川では $\chi$ がどの程度の值となるか について検討する. 前述のように $\chi$ は $C_{D} a D_{c} /\left(2 C_{f}\right)$ であるが, 抗力係数 $C_{D}$ は樹木の抗力係数は樹木が単独 である場合, レイノルズ数が $10^{3} \sim 10^{5}$ の領域では, 1.0
〜1.3であることが，数々の実験によって確かめられて いる ${ }^{15)}$ 。また $\mathrm{Li} \cdot \mathrm{Shen}^{16)}$ は，円柱群が千鳥状に配され ている場合， $C_{D}$ は円柱の間隔の弱い関数となり 1.2 程 度の值をとることを実験によって確かめている。また Ikeda ら ${ }^{10)}$ は, 流路の一部に円柱群を千鳥に配した場合, $C_{D}$ は 1.6 2.0 程度の值となることを実験から得てお り，このように $C_{D}$ が大きくなることを造波抵抗による ものとしている．しかし，実河川における $C_{D}$ の值につ いては不明である。したがって，ここでは中間的な值と して $C_{D}=1.5$ を採用する. $D_{C}$ は中央部における水深で ありここでは $1 \mathrm{~m}$ とする。ささらに $C_{f}$ にいては,

Fig. 6 において用いた 0.00445 を用いる. $a$ は樹木の密 度を表わすパラメーターであり，単位側岸面積当たりに 存在している樹木の幅の和を表わしている．この值は， あまり密度が大きくなると植物の生育に支障が生じる等 の生物学的制約から決定される. 林業では人工的に最大 密度で植えた場合 3000 本/ha 程度まで植林し得るこ とが知られている. また, 直径が $20 \mathrm{~cm}$ 程度にまで成 長した場合， $1 / 3$ 程度間伐する必要があり，したがって $a$ の值は $0.04 \mathrm{~m}^{-1}$ 程度の值がとり得る最大值と考えら れる.このとき，上述の $C_{D}, C_{f}, D_{c}$ の值を用いれば， $\chi=6.7$ となり, $\chi$ の值としてはこの程度の值が最大値 となる。

前述したように $\chi=2$ を超えると摂動パラメーター は 1 を超えることになり， $\phi_{0}, \phi_{1}, \phi_{2} \cdots \cdots \cdots$ が同じオーダー

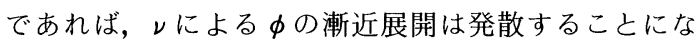
る.ここでは, 接合点における側岸部の内部解の各項, $\phi_{0}, \nu^{1 / 2} \phi_{1}, \nu \phi_{2}$ の值が $\chi$ によってどのように変化する かを調べ，Fig.11に示した.これから実河川がとり得 る值 $\chi=7$ 程度までは発散せず, この領域内で本理論は 有効であると考えられる（限界Ｉ）.

さらに, $\chi=7$ までの領域で Fig. 10 をみると, 流量 $Q$ 
がある値より小さい場合には樹木によって川幅が増大す る効果が現われる. そして，その值は，勾配 $S$ が大き くなるに従って小さくなることがわかる．これは物理的 には次のようなことを意味している．勾配 $S$ が同一で あるとき水深は同一であるから, 流量 $Q$ が小さければ 川幅は小さくなり, aspect 比が小さくなる.すると式

（８）で仮定した河道中央付近で側岸部の影響が無視で きるという仮定が成立しなくなる．ここでは側岸部の影 響が無視できる限界として中央付近の $\phi$ が $0.98, \sigma$ に して 0.96 となる範囲をこの理論の適用限界と考える. この条件を満たす aspect 比の最小值（限界 aspect 比） の $\chi$ による変化を式 (34), (53) （55）を用いて求め たのが Fig. 12 である. $\chi=7$ までの領域ではほぼ一定の 值 8〜9 となり，これ以上であれば適用可能であること がわかる（限界II）.

以上の結果から川幅について適用限界を越える領域を 斜線で示したのが Fig.13である. 有効な領域でも，Q の減少によって樹木の効果は減少する。これは aspect 比が小さい河川の場合，側岸部に樹木があることによっ て生じる流速の欠損が，水深の増大による河積の増大を 相殺するために生じるものと考えられる.

\section{7. 理論結果と野外実測值の比較}

Andrews ${ }^{17}$, Charlton ら ${ }^{18)}$ は側岸部に樹木を有する河 道の流量, 水深, 川幅, 河床材料の粒径等について実測 を行っている. Andrewsによれば側岸に植生 (主に樹木) がある場合にはない場合に比べて，水深が約 $60 \%$ 増加 し，川幅が約 $55 \%$ 減少することが知られている. 樹木 の効果を考慮しないIkeda ら ${ }^{7)}$ の理論を用いて理論値と 実測値の比較を行ったのが Fig. 14 である. 従来の理論 では樹木の密度が高い場合, 水深は実測値よりも小さく, 川幅は実測值よりも大きく見積りすぎていることがわか る. 次に樹木の効果について式 (62) および式 (73) を 用いて検討を行う. Figs. 8, 10 では代表的な $C_{f}$ として 0.00445 を用いたが，ここで用いた観測デー夕は山間部 にある水深の浅い河川であり, 水深之粒径の比の平均値 は, 7.6 (Andrews), 15 (Charlton) と通常の河川より かなり小さくなっている.このような場合には相当粗度 $k$ の值自体が大きくなり, 野外観測の結果から $k=3 d_{90}$ 程度となる ${ }^{5)} こ と か ゙$ 知られており，ここではこの值を用 いる. Andrews, Charlton らのデー夕には，植生の密度

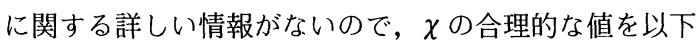
で見積る. Andrews の野外測定では全測定值の平均水 深は $D_{c}=0.80 \mathrm{~m}$ であるので, 平均の $d_{90}=0.11 \mathrm{~m}$ を用 いて式 (69) 加ら平均の $C_{f}=0.021$ となる.さらに前 述の $a=0.04 \mathrm{~m}^{-1}$ を用いると $\chi=1.14$ となる.また Charlton らの野外測定値の平均水深は $D_{c}=1.77 \mathrm{~m}$ であ

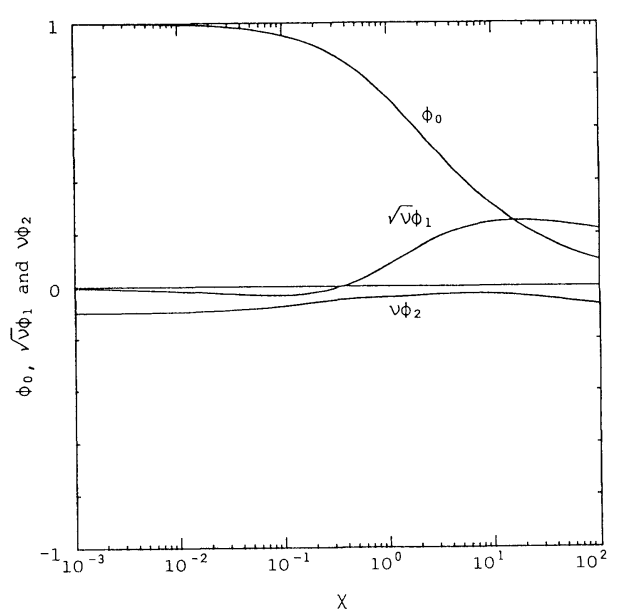

Fig. $11 \phi_{0}, \sqrt{\nu} \phi_{1}$ and $\nu \phi_{2}$ in Eq. (52) versus $\chi$.

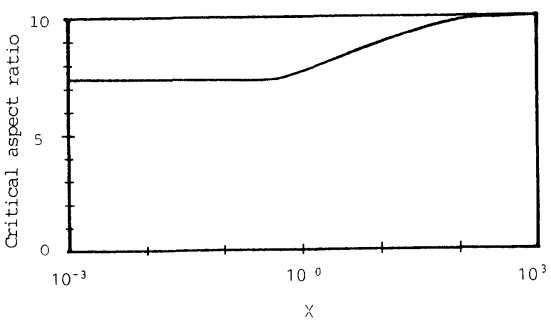

Fig. 12 Critical aspect ratio versus $\chi$.

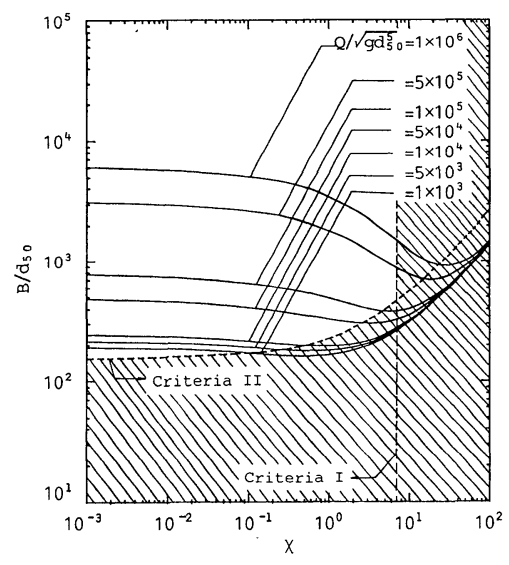

Fig. $13 B / d_{50}$ versus $\chi$ and $Q / \sqrt{g d_{50}^{5}}$, in which hatched region is invalid; $S=0.002, m=2$.

り，同様にして $\chi=3.92$ となる．これらの $\chi$ の值は 7 よりも十分小さく本理論の適用範囲内である.これらの 值を用いて理論值と実測值の比較を示したものが Fig. 15 である. Fig.14でみられた植生のあるなしによ る差異は今回はみられず，実測值と理論值は良好な一致 を示しており，樹木の効果を考慮することの必要性が伺 
われる。

\section{8. 結 論}

本研究により次の諸点が明らかとなった。

（1）水深平均流れの運動量方程式を特異 摂動と接合漸近展開法を用いることによって 解き, 水深平均流速の横断方向分布を側岸に 樹木がない場合について求めた。その流速分 布から底面せん断力の分布を求め接合点で限 界掃流力状態にあることから $\tau_{c}^{*} / \tau_{t h}^{*}$ の值を 求め, 1.23 の值を得た。この值は, Ikeda らが Lundgren・Jonsson の式を用いること によって得た值 1.23 と一致しておりここの 解法の妥当性が示された。

（2）樹木が存在する側岸部の形状は，樹 木の抗力分だけ減少させた底面せん断力を用 い，側岸部全域で静的安定状態にあることか ら求められた。それによると樹木の密度が濃 くなるにつれて側岸部の勾配は急になり，最 終的には側岸部全域で水中安息角となる．ま た，それとともに $2 D_{c} / B_{s}$ の值は增加する ことがわかった。

（3）次に（1）で述べた方法を，樹木を 有する河道に適用することによって底面せん 断力分布を求め, これから動的安定水深が求 められた。また，流路全体としての運動量平 衡（抵抗式）を考えることにより安定川幅が 求められた。樹木の密度が濃くなればなるほ ど安定水深は大きくなり，安定川幅は小さく なることが定量的に明らかとなった．また安 定川幅が減少する効果は, 流量が大きいほど 顕著に現われることが示された。理論値は野 外実測值と比較され, 樹木が濃い場合, $\chi=$ 1.14 (Andrews) , 3.92 (Charlton 引) 程度 と見積った場合の值と良好に一致することが 示された。

（4）樹木の密度を表わす $\chi$ の值は，実 際の河川では最大 7 程度の值をとる.この領 域での摄動解の精度を調べるため, 接合点に おける摂動解の各オーダーの項を比較した結

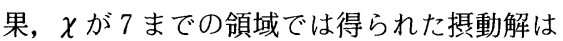
発散せず，本理論は実際の河川に対し適用可 能であることがわかった。 また aspect 比が 小さい河川では，河道中央に側岸の影響が及 ぶため本理論は適用できない，その際，適用 可能な aspect 比の最小値は, 8〜9 となり, これ以上の值であれば本理論は適用できるこ

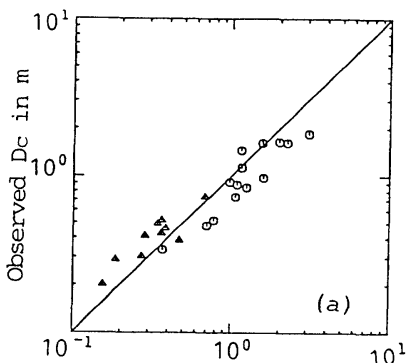

Predicted Dc in $\mathrm{m}$

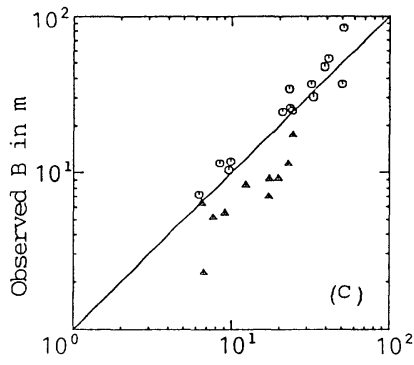

Predicted $\mathrm{B}$ in $\mathrm{m}$

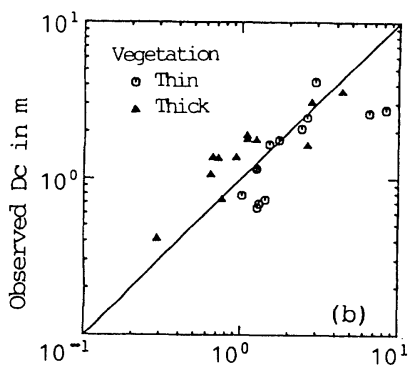

Predicted DC in $\mathrm{m}$

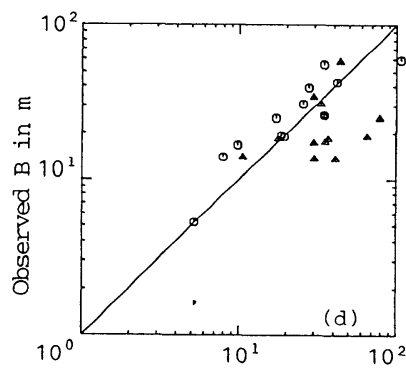

Predicted $\mathrm{B}$ in $\mathrm{m}$

Fig. 14 Test of $D_{c}$ and $B$ by field data, in which vegetation effect is neglected; (a) $D_{c}$ from Andrews, (b) $D_{c}$ from Charlton et al., (c) $B$ from Andrews, (d) $B$ from Charlton et al.

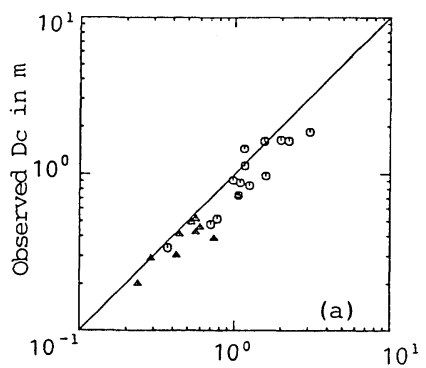

Predicted Dc in $\mathrm{m}$

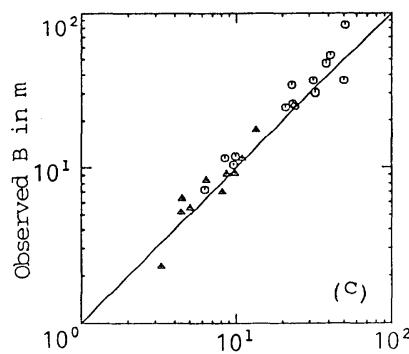

Predicted $B$ in $m$

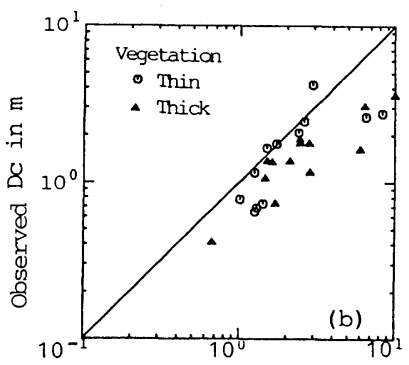

Preducted DC in $\mathrm{m}$

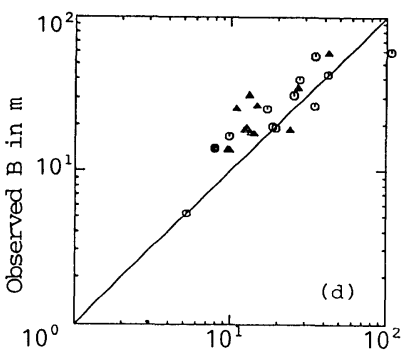

Predicted $\mathrm{B}$ in $\mathrm{m}$

Fig. 15 Test of present theory by field data; (a) $D_{c}$ from Andrews, (b) $D_{c}$ from Charlton et al., (c) $B$ from Andrews, (d) $B$ from Charlton et al. 
とがわかった。

謝辞：本研究に際して文部省科学研究費 “植生が 河川の流れや河道形状に及ぼす効果に関する研究” (一 般 C，代表者：池田駿介）の補助を受けた.

\section{付}

\section{録}

式 (54) から式 (58) 中の係数は次のように表わせる.

$$
\begin{aligned}
\tilde{C}_{0}= & \nu^{-1 / 2} \frac{1-(1+\chi)^{1 / 4}}{(1+\chi)^{1 / 4}} \\
& +\frac{s_{\eta}(0)}{2 \sqrt{2}(1+\chi)^{3 / 2}\left\{1+(1+\chi)^{1 / 4}\right\}}
\end{aligned}
$$

$\hat{C}_{0}=\nu^{-1 / 2}\left\{\frac{1}{(1+\chi)^{1 / 4}}-\frac{1}{(1+\chi)^{1 / 2}}\right\}$

$$
+\frac{s_{\eta}(0)}{2 \sqrt{2}(1+\chi)^{3 / 2}\left\{1+(1+\chi)^{1 / 4}\right\}}
$$

$$
C_{2}=-\frac{\left\{2+(1+\chi)^{1 / 4}\right\}}{6\left\{1+(1+\chi)^{1 / 4}\right\}} \tilde{C}_{0}^{2}-\frac{(1+\chi)^{3 / 4}}{6\left\{1+(1+\chi)^{1 / 4}\right\}} \hat{C}_{0}^{2}
$$$$
+\frac{(1+\chi)^{1 / 4}}{1+(1+\chi)^{1 / 4}} \Xi_{1}+\frac{\hat{C}_{0}}{\sqrt{2}\left\{1+(1+\chi)^{1 / 4}\right\}} \Xi_{0}
$$

$$
\begin{aligned}
\hat{C}_{2}= & -\frac{1}{6\left\{1+(1+\chi)^{1 / 4}\right\}} \tilde{C}_{0}^{2} \\
& -\frac{(1+\chi)^{1 / 2}\left\{1+2(1+\chi)^{1 / 4}\right\}}{6\left\{1+(1+\chi)^{1 / 4}\right\}} \hat{C}_{0}^{2} \\
& -\frac{1}{1+(1+\chi)^{1 / 4}} \Xi_{1}+\frac{\hat{C}_{0}}{\sqrt{2}\left\{1+(1+\chi)^{1 / 4}\right\}} \Xi_{0}
\end{aligned}
$$

$$
\begin{aligned}
& \Xi_{0}=-\frac{4 \chi+3}{8(1+\chi)} s_{\eta}(0) \\
& \Xi_{1}=\frac{s_{\eta \eta}(0)}{4(1+\chi)^{2}}-\frac{2 \chi-1}{8(1+\chi)^{3}} s_{\eta}^{2}(0)-\frac{\sqrt{C_{f}} s_{\eta}^{2}(0)}{4 \alpha(1+\chi)^{1 / 2}}
\end{aligned}
$$

1）高山茂美：河川地形，共立出版，1974.

2) Leopold, L. B. and Maddock, T. Jr. : The hydraulic geometry of stream channels and physiographic implications, U.S. G.S. Prof. Paper, No. 252, 1953.
3) Lane, E. W. : Design of stable channels, Trans. ASCE, Vol.120, pp. 1234 1279, 1955.

4）平野宗夫：拡幅を伴う流路変動について, 土木学会論文 報告集，第 210 号, pp. 13 20, 1973.

5) Leopold, L. B., Wolman, M. G. and Miller, J.P. : Fluvial processes in geomorphology, W. G. Freeman and Company, San Francisco, 1964.

6) Parker, G. : Self-formed straight rivers with equilibrium banks and mobile bed. part 2. The gravel river, J. Fluid Mech., Vol.89, No.1, pp. 127 146, 1978.

7) Ikeda, S., Parker, G. and Kimura, Y. : Stable width and depth of straight gravel rivers with heterogeneous bed materials, Water Resour. Res., Vol.24, No.5, pp. 713 722, 1988.

8）吉川秀夫 ・池田駿介 - 北川 明：湾曲水路の河床変化に ついて, 土木学会論文報告集, 第 251 号, pp. 65 75, 1976.

9) Lundgren, H. and Jonsson, I. G. : Shear and velocity distribution in shallow channels, J. Hydraul. Div., ASCE, Vol. 90, No. HY 1, pp. 1 21, 1964.

10) Ikeda, S., Izumi, N. and Itoh, R. : Effects of piledikes on flow retardation and sediment transport, J. Hydraul. Eng., ASCE，投稿中.

11) Webel, G. and Schatzman, M. : Transverse mixing in open channel flow, J. Hydraul. Eng., ASCE, Vol.110, No. 4, pp. 423 435, 1984.

12) Nayfeh, A.H. : Perturbation methods, John Wiley \& Sons, Inc., 1973.

13) Keulegan, G. H. : Laws of turbulent flow in open chan nels, Research Paper No. RP 1151, NBS, 1938.

14) Egiazaroff, I. V. : Calculation of nonuniform sediment concentration, J. Hydraul. Div., ASCE, Vol.91, No. HY 1, pp. 1 21, 1964.

15) Schlichting, H. : Boundary Layer Theory, 6 th Ed., McGraw-Hill Co., New York, 1968.

16) Li, R. M. and Shen, H.S. : Effect of tall vegetations on flow and sediment, J. Hydraul. Div., ASCE, Vol. 99, No. HY 5, pp. 793 814, 1973.

17) Andrews, E. D. : Bed-material entrainment and hydraulic geometry of gravel-bed rivers in Colorado, Geol. Soc. America Bull., Vol.95, pp. 371 378, 1984.

18) Charlton, F.G., Brown, P.M. and Benson, R.W. : The hydraulic geometry of some gravel rivers in Britain, Wallingford, Great Britain, Hydraulics Research Station, 48 p., 1978.

（1989.6.17・受付 